\title{
Estimate some immunoglobulin's and complement cascade in pregnant women suffering from urinary tract infection
}

\author{
Fidan Fikrat Ahmed \\ Northern Technical University, Health and Medical Technical College/ Kirkuk, Iraq. \\ fidanfikrat1972@ntu.edu.iq
}

\begin{abstract}
The objective of this study is a measurement of some immunoglobulin's (IgM and $\mathrm{IgG})$ and complement cascade $(\mathrm{C} 3, \mathrm{C} 4)$ in pregnant women suffering from urinary tract infections (UTI) by single radial Immunodiffusion test 30 samples of urine and the blood were collected from pregnant female infected by UTI and 10 specimens were collected from healthy pregnant women in the period from December 2020 to June 2021 the samples were taken from pregnant female and they're aged ranging from 18 to 30 years. The results of the study showed that the levels of IgG is higher in those with UTI the mean is in the three trimesters respectively than in control and there's a statistically significant in the first trimester only with $\mathrm{P} \leq 0.05$. In UTI patients, the results appeared a elevate in the level of C3 and C4 in those with UTI is higher in the first and third trimester, however, it's slightly lower in UTI patients than in control in the second trimester, there's no statistical significance between those with UTI and control. Otherwise, the results demonstrated that the level of hepcidin in UTI patients increased compared with control in the first, second and third trimesters respectively.
\end{abstract}

Keywords: Urinary tract infection; immunoglobulin; complement cascade

\section{Introduction}

The infections of the urinary tract (UTIs) are described as bacterial infections, and affect about 150 million people per year universally [1]. UTI is generally caused by different types of bacteria, and also various microorganisms like fungi and some viruses [2]. The type of UTI infection is usually classified as complicated and uncomplicated infections. The uncomplicated UTI type happens in the absence of functional or structural deformity within the urinary system. The complicated infections are happening in presence of deformity urinary tract that elevated the sensitivity to bacterial infection [3-4]. The family of Enterobacteriaceae is responsible for the infections of the urinary tract in man. E. coli is classified as the most frequent uropathogen [5]. the immunoglobulins describe as a category of proteins found in serum that play a significant role as antimicrobial activity in urinary tract infections where the IgM type represents an indicator of new infection with pathogens, the levels of $\operatorname{IgG}$ were elevated in the chronic infections, and IgA consists of the secretory part that assists in decreasing the infections 
of mucosal membrane and secretory based. However, the role of the complement system especially for C3 in recurrent UTIs is still debatable [6]. UTIs in pregnant females continue to demonstrate a clinical issue [7]. Although the occurrence of bacteriuria in pregnant women is slightly higher compared with a non-pregnant female, its effects for mother and fetus are more severe [8-9].

\section{Materials \& Methods}

\subsection{Sample Collections}

The study was performed during the period from December 2020 to June 2021 with the collection of 70 samples of serum and urine from pregnant women with ages ranging from 18-30 years. 50 of them were suspected to be infected with UTI and 20 pregnant women without any infection symptoms as the control group. The last menstrual period and the number of times they had a pregnancy were all recorded.

\subsection{Microscopic examination}

The samples of urine were collected from pregnant women in clean disposable cups and a portion of the sample is placed in a test tube and centrifuged at $400 \mathrm{x} g$ for 5-10 minutes and the sediment was examined under the light microscope for the presence of pus cells and $\mathrm{RBC}[10]$.

\subsection{Radial Immunodiffusion test}

Single Radial Immunodiffusion (SRID) tests were used for the quantitative determination of many human serum proteins such as IgG, IgM, and C3, C4 complements. The sera were removed from freezing and equilibrated to room temperature. Plates were getting refrigerator then the zip lock bag and lid removed, wells were inspected for moisture. The serum of infected women and control were shaken (in their containers) by inversion, each sample was dispensed onto the wells. Each well-required $5 \mu$ of serum. After the lid was replaced, it was incubated in an incubator at $37 \mathrm{c}$. Incubation time was 72 hours. Immunoprecipitation ring diameters were measured by hand lens $(0.1 \mathrm{~mm}$ precision $)$. The calculated diameters were compared to the standard diameter to conclude the concentrations of serum humoral factors [11].

\subsection{Hepcidin measurement}

The levels of hepcidin were measured inpatient and control serum by using an Enzymelinked immunosorbent assay (ELISA) depending on the technology of the biotin double antibody sandwich

\subsection{Statistical analysis}

The results and the data of current work were analysed by utilizing the program called Statistical Package for Social Sciences (SPSS-17), and significant changes between the means of studied groups were compared at the level of probability $\mathrm{P}<0.05$

\section{Results and discussion}

Out of 70 pregnant females, $50(71.4 \%)$ had UTI and $20(28.6 \%)$ women as control. the isolation of bacteria from the urine samples including E. coli, S. aureus, Klebsiella, and proteus 
[12]. In the present work, the incidence of UTI was significantly high. The high percent of infection may be back to the majority of females in current work belonged to socioeconomic with lower and/or middle levels; this theory is supported by various studies that referred that the UTI has happened at a higher rate among pregnant females living in status with poor socioeconomic [13-14]. The isolated bacteria from the urine sample in the present work was $E$. coli and this agreed with the findings of previous studies [15-18]. The flora located in faeces serves as the source of $E$. coli that colonizes the introitus of the vagina and urethra to bladder infection [19].

\section{Immunological study}

The samples of serum from infected women with UTI and those who were healthy were tested to diagnose $\mathrm{IgM}, \mathrm{IgG}, \mathrm{C} 3$, and $\mathrm{C} 4$ by immunodiffusion plates, and the findings of this work were demonstrated that the IgG, IgM, C3 and C4 levels in infected pregnant with UTI and control subjects without UTI are showed in the table (1) expressed as mean \pm SD. Also, the estimates of hepcidin levels were done according to the procedure of the kit.

Table 1: Serum Immunoglobulin's (IgG and IgM) in pregnant women infected with UTIs compared with control subjects.

\begin{tabular}{|c|c|c|c|}
\hline Parameter & Months & Control $($ mean \pm SD $)$ & $\begin{array}{l}\text { Patients With UTI } \\
\quad(\text { mean } \pm \text { SD })\end{array}$ \\
\hline \multirow{3}{*}{ IgM mg/d } & $1-3$ & $134.4 \pm 10.23 b$ & $206.1 \pm 14.45$ a \\
\hline & $4-6$ & $151.3 \pm 5.19 b$ & $283.12 \pm 8.03$ a \\
\hline & $7-9$ & $103.5 \pm 13.42 b$ & $238.33 \pm 10.52 a$ \\
\hline \multirow{3}{*}{ IgG mg/d } & $1-3$ & $1026.6 \pm 19.51 \mathrm{a}$ & $911.5 \pm 11.5 b$ \\
\hline & $4-6$ & $1146.3 \pm 27.62 \mathrm{a}$ & $824.9 \pm 61.4 b$ \\
\hline & $7-9$ & $973 \pm 18.72 a$ & $793.1 \pm 13.4 \mathrm{~b}$ \\
\hline
\end{tabular}

The results in Table (2) show the mean concentrations of $(\mathbf{C 3}, \mathbf{C 4})$ for each of the positive patients (pregnant women which suffering from UTIs) and also for control (without UTI), according to the trimesters of pregnancy. Otherwise, the present results show a significant increase in UTI patients compared with the control group, as shown in table (3). 
Table 2: Serum Complement components (C3 and C4) in pregnant women infected with UTIs compared with control subjects.

\begin{tabular}{|c|c|c|c|}
\hline Parameter & Months & Control $($ mean \pm SD) & $\begin{array}{l}\text { Patients With UTI } \\
\quad(\text { mean } \pm \text { SD })\end{array}$ \\
\hline \multirow{3}{*}{$\mathrm{C} 3(\mathrm{mg} / \mathrm{d})$} & $1-3$ & $94.21 \pm 8.2 b$ & $152.5 \pm 3.08 \mathrm{a}$ \\
\hline & $4-6$ & $84.2 \pm 4.28 b$ & $104.35 \pm 6.14 \mathrm{a}$ \\
\hline & $7-9$ & $71.73 \pm 6.5 b$ & $93.31 \pm 4.01 \mathrm{a}$ \\
\hline \multirow{3}{*}{ C4 (mg/d) } & $1-3$ & $134.8 \pm 8.01 b$ & $193.3 \pm 9.8 \mathrm{a}$ \\
\hline & $4-6$ & $131.3 \pm 12.4 b$ & $197.33 \pm 13.82$ a \\
\hline & $7-9$ & $128.22 \pm 9.36 b$ & $184.1 \pm 8.42 \mathrm{a}$ \\
\hline
\end{tabular}

Table 3: Serum hepcidin in pregnant women infected with UTIs compared with control subjects.

\begin{tabular}{|c|c|c|c|}
\hline Parameter & Months & Control (mean \pm SD) & $\begin{array}{l}\text { Patients With UTI } \\
\quad(\text { mean } \pm \text { SD })\end{array}$ \\
\hline \multirow{3}{*}{$\begin{array}{l}\text { Hepcidin } \\
\text { ng/ml }\end{array}$} & $1-3$ & $12.64 \pm 1.04 b$ & $14.6 \pm 1.16$ a \\
\hline & 4-6 & $13.27 \pm 1.62 \mathrm{~b}$ & $18.83 \pm 0.72 \mathrm{a}$ \\
\hline & $7-9$ & $15.18 \pm 1.74 b$ & $25.17 \pm 2.61 \mathrm{a}$ \\
\hline
\end{tabular}

The present work demonstrated elevated levels of IgG in UTI patients; others have reported the same investigation in their works about the protective immunity role against infection of the parasite [20]. The important and protective act of IgG versus pathogens explains the significantly elevated levels of $\operatorname{IgG}$ found in the UTI women in the current study, since it is the immunoglobulin synthesis and secreted during the secondary immune response. Elevate the values of IgM as recorded in patients of UTI, the same observation was reported by another study [21]. Elevate in complement's element may show by a variety of explanations, one interesting activity depends on outcomes of [22]. UTI infection attributed the increase of complement component production to the stimulation of the inflammatory mediators [23]. The immunity of maternal is altered during pregnancy time to favour implantation and growth of the embryo. The study suggests that immune response is modulated by humoral immune response 
[24]. The present findings demonstrated significant elevate in patients with UTI, where the level of hepcidin elevates in the infection, thus limiting iron produced and released into the blood and disrupting pathogen growth [25]. The current findings agree with [26] who referred that hepcidin and the levels of ferritin were significantly elevated, whereas the levels of iron significantly reduced in the children with a bacterial infection.

\section{References}

1. Flores-Mireles, A. L.; Jennifer N. W.; Michael C. and Scott J. H. (2015). Urinary tract infections: epidemiology, mechanisms of infection and treatment options. Nat. Rev. Microbiol. 13(1): 1-17.

2. Olin SJ, Bartges JW (2015) Urinary tract infections: treatment/comparative therapeutics. Vet Clin North Am Small Anim Pract 45:721-746

3. Bazzaz, B. S. F.; Sareh D. F.; Reza A. and Bahman K. (2021). Deep insights into urinary tract infections and effective natural remedies. Afr J Urol. 27(6): 1-13.

4. Sheerin NS, Glover EK (2019) Urinary tract infection. Medicine 47:546-550.

5. Dlakhal, Z. A. (2013). Bacterial isolates associated with urinary tract infections in children. Misan J. Aca. Stu. 12(22): 56-60.

6. Hooton TM. Uncomplicated urinary tract infection. New Engl J Med. 2012; 366: $1028-1037$

7. Hannan TJ, et al. Host-pathogen checkpoints and population bottlenecks in persistent and intracellular uropathogenic Escherichia coli bladder infection. FEMS Microbiol Rev. 2012; 36: 616-648.

8. Soman N. Abraham \& Yuxuan Miao. The nature of immune responses to urinary tract infections. Nature Reviews Immunology volumel5 (2015); pages655-663.

9. Foxman B. Epidemiology of urinary tract infections: incidence, morbidity, and economic costs. Am J Med 2002; 113: 5-13.

10. Schnarr J, Smaill F. Asymptomatic bacteriuria and symptomatic urinary tract infection in pregnancy. Eur J Clin Invest 2008; 38 (Suppl. 2): 50-7

11. Mazor-Dray E, Levy A, Schlaefer F, Sheiner E. Maternal urinary tract infection: is it independently associated with an adverse pregnancy outcome? J MaternFetal Neonatal Med 2009; 22: 124-32.

12. Bolton $\mathrm{M}$, Horvath $\mathrm{DJ}$, $\mathrm{Li} \mathrm{B}$, et al. Intrauterine growth restriction is a direct consequence of localized maternal uropathogenic Escherichia coli cystitis. Plus, ONE 2012; 7: 1-9.

13. Vandepitte, Jozef, Engbaek, Kraesten, Rohner, P, Piot, Peter, Heụck, Claus C. et al. (2003). Basic laboratory procedures in clinical bacteriology / J. Vandepitte L. 2nd ed. Geneva: World Health Organization.

14. Franklin, R.; Matthew, A.; Karen, B.: Michael, N. George M; Dwight, J. et al. Performance Standards for Antimicrobial Susceptibility Testing: Twenty-First Information Supplement. Clinical and laboratory standards institute (CLSI) sl. (2011); Vol.31 (1).

15. Schaeffer, A.J. Infections of the urinary tract. In: Walsh, P.C.; Retik, A.B.; Vaughan, E.D.; Wein, A.J.; Campbells Textbook of Urology. 7th Edn. WB. Anders company: London; (1998); p: 534614. 
16. Sheikh, M.A.: khan, M.S.; khatoon, A. and Arain, G.M. Incident of urinary tract infection during pregnancy. Eastern Mediterranean Health Journal. (6), (2000); p: 265-271.

17. McCormick, T.; Ashe, RG.; Kearney, PM Urinary infection tract in pregnancy. The Obstetrician and Gynaecologist; 10: (2008): 156-62

18. Moghadas, AJ and Irajian, G. Asymptomatic urinary tract infection in pregnant women Iranian journal of pathology (3), (2009) p 105-108.

19. Suman, E. Bhat, GK and Hegde, BMBacterial adherence and immune response in recurrent urinary tract infection. J Gynec Obstet. (75) (2001); p: 263-268.

20. Colgan, R.; Nicolle, LE.; McGlone. A.and Hooton, TM Asymptomatic bacteriuria in adults. Am Fam Physician.; 746 (2006): p985-90

21. Hernandez BF Lopez Carmona JM Rodriguez M Peralta Pedrero ML Rodriguez Gutierrez RS and Ortiz Aguirre AR in pregnant women bacteria Asymptomatic and uropathogenic in vitro antimicrobial sensitivity GinecolObstet Mix 75 (6) (2007) p: 325-31.

22. Stamey, TA Pathogenesis and treatment of urinary tract infections. The Williams and Wilkins Co., Baltimore, Maryland.

23. Ramirez, R.M.; Ceballos, E.; Alarcon de Noya, B.; Noya, O. and Bianco, N. The immunopathology of human schistosomiasis III immunoglobulin isotype profiles and response to praziquantel. Men. Inst. Oswaldo Cruz. (91). (1996); p: 593-599.

24. Arinola, O.G.; Salawu, L. and Ojurongbe, O. Immunoglobulin classes (IgG, $\operatorname{IgA}$, and IgM) and acute-phase proteins in the pregnant woman with urinary schistosomiasis. WAJM. (24) 1. (2005); P: 44-48.

25. Miletic, VD.; Hester, CG and Frank, MM) Regulation of complementary activity by immunoglobulin. I. Effect of immunoglobulin isotype on C4 uptake on antibodysensitized sheep erythrocytes and solid-phase immune complexes. J Immunol. 15612) (1996); p: 749-57.

26. Botto, M.; Kirschfink, M.; Macor, P.; Pickering, M.C.; Wurzner, R. and Tedesco, F. Complement in human (2009).

27. Wegmann, T.G., Lin, H.; Guilbert, L. and Mosmann, T. R. Bidirectional cytokine interactions in the maternal-fetal relationship: is successful pregnancy a $\mathrm{TH} 2$ phenomenon? Immunology Today: (14): (1993); 353-3566.

28. Rishi G, Wallace DF, Subramaniam VN. Hepcidin: regulation of the master iron regulator. Biosci Rep 2015;35. pii: e00192.

29. Kossiva L, Gourgiotis DI, Tsentidis C, Anastasiou T, Marmarinos A, Vasilenko H, et al. Serum hepcidin and ferritin to iron ratio in evaluation of bacterial versus viral infections in children: a single-center study. Pediatr Infect Dis J 2012;31: 795e8. 